\title{
Water-balance approach for assessing potential for smallholder groundwater irrigation in Sub-Saharan Africa
}

\author{
P Pavelic ${ }^{\text {* }}$, V Smakhtin ${ }^{2}$, G Favreau ${ }^{3}$ and KG Villholth ${ }^{4}$ \\ ${ }^{1}$ International Water Management Institute, Vientiane, Lao PDR \\ 2International Water Management Institute, Colombo, Sri Lanka \\ IIRD, HydroSciences Montpellier, France \\ ${ }^{4}$ International Water Management Institute, Pretoria, South Africa
}

\begin{abstract}
Strategies for increasing the development and use of groundwater for agriculture over much of Sub-Saharan Africa (SSA) are urgently needed. Expansion of small-scale groundwater irrigation offers an attractive option to smallholder farmers to overcome unreliable wet-season rainfall and enhance dry-season production. This paper presents a simple, generic groundwater-balance-based methodology that uses a set of type-curves to assist with decision making on the scope for developing sustainable groundwater irrigation supplies, and to help understand how cropping choices influence the potential areal extent of irrigation. Guidance to avoid over-exploitation of the resource is also provided. The methodology is applied to 2 sites in West Africa with contrasting climatic and subsurface conditions. At both sites the analysis reveals that there is significant potential for further groundwater development for irrigation whilst allowing provisions for other sectoral uses, including basic human needs and the environment.
\end{abstract}

Keywords: groundwater irrigation, water balance, over-exploitation, Sub-Saharan Africa

\section{Introduction}

Enhanced groundwater irrigation for smallholder agriculture in Sub-Saharan Africa (SSA) is widely recognised as being an important aspirational goal that would dramatically improve food security and livelihoods by protecting against poor and highly variable wet-season rainfall and by enabling productive use of land during the dry season (Kay, 2001; Allaire, 2009). However, groundwater-sourced agricultural development across SSA has been severely lagging behind most other regions of the world (Shah et al., 2007). Less than $2 \%$ of rural households are served by groundwater for irrigation purposes in SSA, whereas, in contrast, the figures for China and India may be in the order of $30 \%$ and $50 \%$, respectively (Giordano, 2005). According to national-level figures from a cross-section of 16 SSA countries, groundwater is being used to irrigate less than $1 \%$ of the arable land (Table 1). At the same time, positive developments are emerging, with groundwater being increasingly recognised as a largely untapped resource for agricultural development in SSA, albeit with numerous technical and non-technical issues which severely constrain development (Giordano, 2006; Masiyandima and Giordano, 2007). There is emerging evidence that farmers are increasingly resorting to groundwater for irrigating high-value crops across Ghana where there is much optimism amongst decision-makers and investors that groundwater can play an important role in enhancing productivity and alleviate poverty (Namara et al., 2011). Other successful examples of agricultural groundwater development, often using rudimentary abstraction technologies

This paper was originally presented at the International Conference on Groundwater: Our Source of Security in an Uncertain Future, Pretoria, 19-21 September 2011.

* To whom all correspondence should be addressed.

용 +856-21-771438; fax: +856-21-770076; e-mail:p.pavelic@.cgiar.org include the fadama cropping systems along the inland valley areas of Nigeria (Tarhule and Woo, 1997). In countries such as Ethiopia and Zimbabwe, smallholder farmers with higher, yearround access to irrigation water through the use of groundwater are better able to produce higher-valued, marketable vegetables than those without (Hagos et al., 2009). These examples offer hope for the expansion of areas under cultivation and higher cropping intensities if technical, technological, economic and policy-related barriers can be overcome.

One of the issues that must be addressed when proposing new groundwater irrigation development for smallholder farmers is the threat of over-abstraction posed to existing groundwater users, along with the ecosystems supported by groundwater. In countries such as South Africa, where groundwater irrigation development is the most advanced within the SSA region (Table 1), as well as in some other countries in the lower rainfall zones, commercial-scale developments have in some cases already led to continuously falling groundwater levels (Wada et al., 2010).

Across much of the region, very little is known about the physical extent, accessibility and development potential of groundwater, but interest and knowledge are emerging (Namara et al., 2011). Data availability remains scarce, and that which is being gathered is often being collected unsystematically and disconnected from information systems (Adelana and MacDonald, 2008). Not only is the quantum of information and the level of understanding often very poor, it is also highly heterogeneous across the region, which makes it difficult to perform broad-scale assessments. As a result, uncertainties and misconceptions emerge about the development potential.

In areas where the development of the groundwater resources is low, the extent of smallholder irrigation that could be introduced is usually unknown. Given the above-mentioned challenges, simple methods that follow 'start small and learnas-you-go' principles are needed in order to gauge the levels of irrigation development that can be sustained, and to determine 
strategies to ensure that the appropriate type and level of development will take place. In this paper a simple methodological framework is presented that aids in the estimation of upper limits of groundwater development for irrigation in terms of volumes of abstraction and irrigated area. The methodology is then applied to 2 case-study areas in West Africa to demonstrate its applicability and utility.

\begin{tabular}{|l|c|c|}
\hline \multicolumn{3}{|c|}{$\begin{array}{c}\text { Table 1 } \\
\text { Estimates of groundwater use for irrigation } \\
\text { in selected Sub-Saharan African countries. } \\
\text { Sources: Siebert et al. (2010) and FAOSTAT (2011) }\end{array}$} \\
\hline Country & $\begin{array}{c}\text { Groundwater } \\
\text { irrigated area (ha) }\end{array}$ & $\begin{array}{c}\text { Percentage of } \\
\text { arable land }\end{array}$ \\
\hline Botswana & 286 & 0.11 \\
\hline Burkina Faso & 3000 & 0.05 \\
\hline Ethiopia & 2611 & 0.39 \\
\hline Ghana & 12000 & 0.27 \\
\hline Kenya & 970 & 0.02 \\
\hline Malawi & 30 & 0.00 \\
\hline Mali & 750 & 0.02 \\
\hline Mozambique & 217 & 0.00 \\
\hline Niger & 1221 & 0.01 \\
\hline Nigeria & 64000 & 0.17 \\
\hline South Africa & 127330 & 0.88 \\
\hline Sudan (N\&S) & 29732 & 0.14 \\
\hline Tanzania & 17465 & 0.18 \\
\hline Uganda & 59 & 0.00 \\
\hline Zambia & 6646 & 0.28 \\
\hline Zimbabwe & 14277 & 0.38 \\
\hline
\end{tabular}

\section{Methodological development}

\section{Principles and approach}

In groundwater systems that are actively replenished, it is generally accepted that the sustainable yield of an aquifer determines the allowable extent of groundwater abstraction within acceptable levels of stress that maintains and protects dependent social, economic and environmental values (Alley and Leake, 2004). Typically, estimates of sustainable yield are arrived at by detailed and systematic analysis of groundwaterflow systems that uses numerical modelling techniques and are underpinned by data on aquifer properties, boundary conditions, recharge rates, groundwater use, etc. In this context where data upon which to define such limits are sparse or nonexistent, it may be argued that sustainable yield concepts still carry meaning, but the question remains as to how to determine upper limits to groundwater development, allocation for various potentially competing uses, development impacts, and how to put in place control systems that enable the acceptable levels of development to be defined over time as data and knowledge are improved.

Whilst it is a given that any level of groundwater development will create an impact on water levels, and sometimes on water quality, the main issue is the extent to which this impact can be tolerated by water resource managers and communities, and whether the socio-economic benefits derived from groundwater use outweigh the costs to members of the community who do not gain directly or indirectly from the groundwater, as well as the extent to which groundwater-dependent ecosystems are affected. This translates to the avoidance of groundwater over-exploitation and the protection of other beneficial uses, including wetlands, springs, groundwater seepage areas and groundwater-fed dry-season river flows.

A relatively simple method, based on an overall groundwater balance, can be set up for the initial, first-order estimation of the upper limit of groundwater use for irrigation, or the potential areal extent of cultivation with irrigated crops. For the purpose of this analysis, let us consider the groundwater system to comprise of 2 discrete components, namely an underlying one that provides ambient storage, and another overlying one that consists of active storage which is seasonally replenished by rainfall-recharge through diffuse and/or more localised mechanisms (Fig. 1). The ambient component represents the long-term, relatively stable storage whilst the active storage is subject to annual groundwater-level fluctuations due to recharge and discharge fluxes. This is consistent with longterm sustainability if it is assumed that use is derived preferentially from the upper component, and within this component, there is provisioning for the various sectoral requirements, namely domestic and livestock needs, industry, irrigation, and environmental uses. This concept can be expressed as an annual groundwater balance:

$$
R_{\mathrm{t}}=Q_{\mathrm{d}}+Q_{1}+Q_{\mathrm{in}}+Q_{\mathrm{i}}+Q_{\mathrm{e}}+Q_{\mathrm{uc}}
$$

where:

$R_{\mathrm{t}}=$ total mean annual recharge (or active storage), $\left(\mathrm{mm} \cdot \mathrm{yr}^{-1}\right)$

$Q_{\mathrm{d}, \mathrm{l}, \mathrm{i}, \mathrm{ie}}=$ discharge to service domestic, livestock, industry, irrigation and the environmental needs, respectively $\left(\mathrm{mm} \cdot \mathrm{yr}^{-1}\right)$

$Q_{\text {uc }}=$ uncommitted surplus water for future anthropogenic uses, over and above the other 5 components, so as to complete the balance, $\left(\mathrm{mm} \cdot \mathrm{yr}^{-1}\right)$

The fraction of the active storage that is allocated to any sector can be calculated. In the case of irrigation $\left(f_{\mathrm{i}}\right)$ it is simply:

$$
f_{\mathrm{i}}=Q_{\mathrm{i}} / R_{\mathrm{t}}
$$

The underlying ambient storage component is identified here as it provides buffering against extreme climate shocks, particularly prolonged drought, and offers additional environmental support. Interaction and exchange of water can take place between the upper and lower components. Whilst the ambient storage may provide reserves that can be intermittently drawn upon, it may be limited or even non-existent in certain settings, such as the crystalline basement aquifers prevalent in SSA.

The question concerning which physical scale to consider is vexed and dependent upon a range of factors. Rather than attempt to prescribe a specific scale of interest here, the concept of a 'management unit' is offered which represents any scale at which groundwater resources need to be managed. It may represent a hydrological unit such as a river basin or aquifer, but not necessarily so, and extend from the regional scale at one extreme through to the farm scale at the other end of the spectrum.

For any given value of $Q_{\mathrm{i}}$ the relative area of the management unit $\left(A_{\mathrm{mu}}\right)$ that may be used for irrigation $\left(A_{\mathrm{i}} / A_{\mathrm{mu}}\right)$ is a function of total recharge $\left(R_{\mathrm{r}}\right)$ and the total seasonal net irrigation (evapotranspiration) water demand of a particular crop $\left(Q_{\mathrm{c}}\right)$ :

$$
A_{\mathrm{i}} / A_{\mathrm{mu}}=\left(f_{i} \times R_{\mathrm{t}}\right) / Q_{\mathrm{c}}
$$


Figure 1

Total groundwater storage partitioned into ambient and active storages, with the latter indicative of replenishment that is allocated to 5 primary beneficial uses and an uncommitted reserve
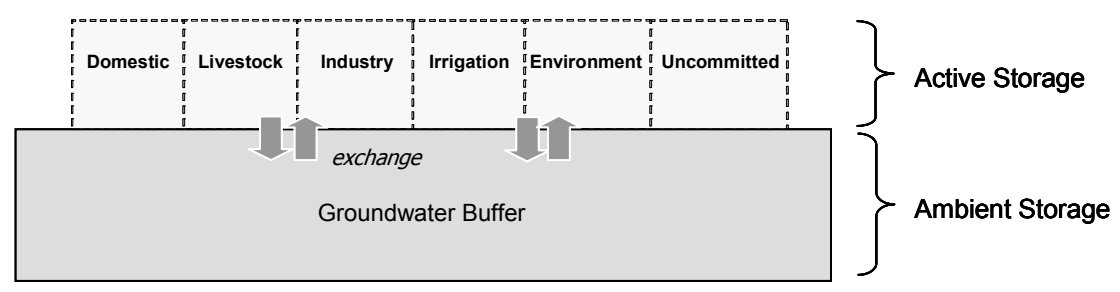

The key assumptions implicit in the approach are:

- Aquifers systems are actively recharged by modern rainfall-derived recharge.

- Recharge and discharge fluxes are multi-year averages that balance out inter-annual fluctuations.

- $Q_{\mathrm{d}}, Q_{1}$ and $Q_{\text {in }}$ are known or estimated a priori. If unknown, then local data on population numbers and per capita water consumption for humans and livestock can be taken from the literature or existing databases (e.g. FAOSTAT).

- The groundwater system is at quasi-steady state such that groundwater inflows and outflows at the management scale do not change significantly over the long term.

- Groundwater quality does not create a major constraint to the sectoral uses.

- Groundwater reserved for ecological purposes, although unknown over the greater majority of SSA, is embedded within the $Q_{\mathrm{e}}$ component.

- Average fluxes over the area in question are used. Whilst aggregation at the management scale must take place, the heterogeneities that exist within the landscape are still recognised. Not all sub-areas have the same development potential due to, for example, spatial variability in recharge and constraints in water quality and soil fertility.

- $Q_{\mathrm{c}}$ represents the net beneficial as well as non-beneficial evapotranspiration from cropped areas.

- Groundwater use represents net losses from the groundwater reserve (i.e. negligible influence between the groundwater and surface water systems).

- An average annual effective crop water demand (above rainfall inputs) is satisfied by groundwater. This may represent one or more crop types and multiple cropping seasons that are aggregated over the year.

This approach bears similarity to the water-balance approach proposed by Wright and Xu (2000) for South Africa while focusing on identifying limits for groundwater use for irrigation. An alternative approach, proposed by Seward et al. (2006) uses the concept of 'capturable' storage rather than recharge to define sustainability criteria. This approach is probably more accurate than that proposed here, since it describes the physical processes more accurately, but application is limited to cases where there is sufficient data. It is also worthwhile noting the work of Dillon et al. (2009) who used a simple mass-balance approach to assess the sustainability of groundwater irrigation, but with a focus on the role and significance of managed aquifer recharge as supply-anddemand-based counterbalances to the problem of groundwater overdraft.

Total mean annual recharge represents net water replenishing groundwater from various sources, such as rainfall percolation and/or focused recharge from surface water bodies (lakes and rivers, etc.). It is of importance since it governs not only the development potential but also the sustainability of groundwater use. The conundrum is that there are really only 2 main ways it can be derived; one based on regional scale modelling

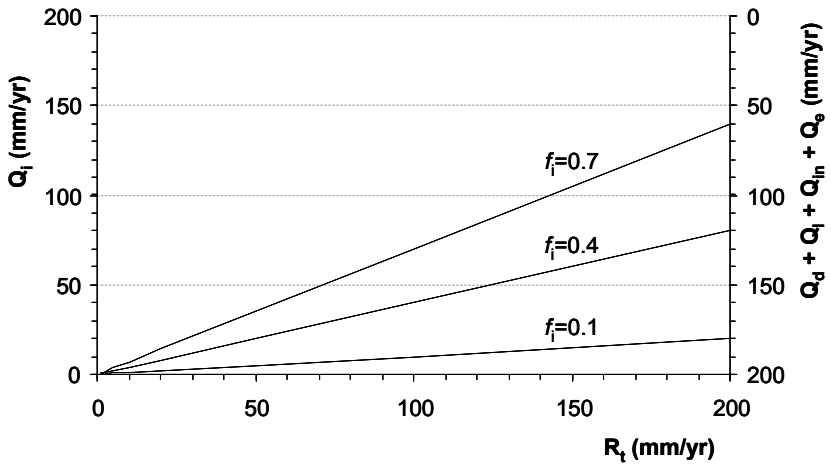

Figure 2

Type-curves indicating the relationship between the amount of irrigation $\left(Q_{i}\right)$ which can be sustained for different levels of groundwater recharge $\left(R_{t}\right)$ and allocations to irrigation (f)

approaches that are reliant upon climate data, and basically considers direct rainfall as sole source of recharge and natural vegetation cover (e.g. Döll et al., 2002); and the other from point measurements, which are more accurate but subject to large spatial variability (e.g. Scanlon et al., 2006). The modelling work of Döll et al. (2002) suggests potential values of, at most, $200 \mathrm{~mm} \cdot \mathrm{yr}^{-1}$ in all but the moist central-western region of Africa. Whilst inaccurate at specific locations, this provides a guide as to the end-members for consideration. MacDonald et al. (2009) classified Africa into 3 broad recharge zones: negligible recharge in areas of $200 \mathrm{~mm} \cdot \mathrm{yr}^{-1}$ rainfall; up to 50 $\mathrm{mm} \cdot \mathrm{yr}^{-1}$ recharge for rainfall in the range of $200 \mathrm{~mm} \cdot \mathrm{yr}^{-1}$ to 500 $\mathrm{mm} \cdot \mathrm{yr}^{-1}$; and greater than $50 \mathrm{~mm} \cdot \mathrm{yr}^{-1}$ recharge where rainfall exceeds $500 \mathrm{~mm} \cdot \mathrm{yr}^{-1}$. This generally conforms with the review of recharge studies conducted in 5 arid and semi-arid African countries by Scanlon et al. (2006) that suggests values of $<60$ $\mathrm{mm} \cdot \mathrm{yr}^{-1}$.

Under conditions of high spatial variability the approach can be suitably modified. For example, in the case of large management units with high rainfall variability, effective values may be difficult to derive or of limited value. In such cases, some degree of disaggregation may be desirable to cover separate recharge zones.

The approach presented above is largely driven by recharge, which is difficult to derive to any degree of accuracy without detailed studies. Where uncertainty exists, conservative principles should be applied; effectively this translates into using lower-bound estimates of supply and upper-bound estimates of demand as the safest bet for deriving a lower-limit of $Q_{\text {uc }}$, the unallocated residual.

From Eqs. (1) to (3) above, it is possible to define a series of type-curves that identify water-allocation options under different recharge regimes. Figure 2 provides such curves for 3 contrasting values of $f_{\mathrm{i}}$. It shows, for example, that in the case of the lowest value of $f_{\mathrm{i}}=0.1$, the upper-limit for irrigation $Q_{\mathrm{i}}$ (basin-wise) would be $20 \mathrm{~mm} \cdot \mathrm{yr}^{-1}$ whereas in the highest case considered $\left(f_{\mathrm{i}}=0.7\right)$ it may reach $140 \mathrm{~mm} \cdot \mathrm{yr}^{-1}$. Often, $f_{\mathrm{i}}$ is not 


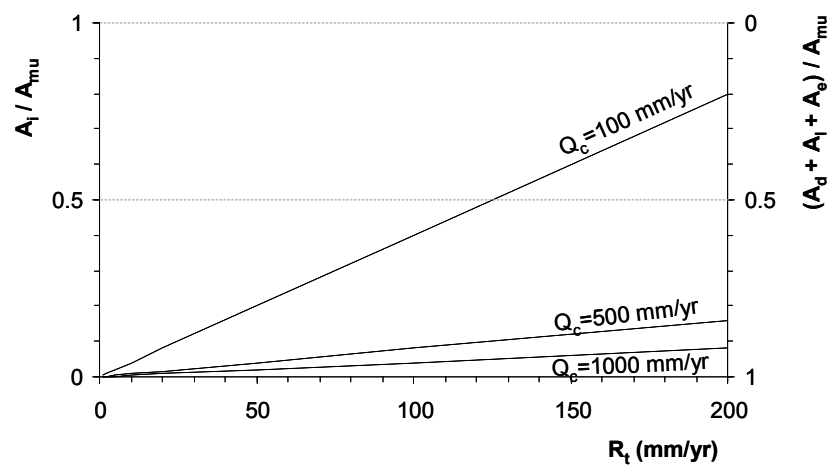

Figure 3

Type-curves indicating the relative proportion of irrigated area $\left(A / A_{\text {mu }}\right)$ for the case of $f_{i}=0.4$ as a function of groundwater recharge $(R)$ for 3 levels of irrigation water demand $(Q)$ : high, medium and low

given or known a priori but can be calculated from estimates of $R_{\mathrm{t}}$ and uncommitted reserves (i.e. accounting for $Q_{\mathrm{d}}+Q_{1}+Q_{\mathrm{in}}$ $+Q_{\mathrm{e}}$ ). For $Q_{\mathrm{e}}$, environmental flow requirement considerations can be included, which in the South African context has been referred to as an 'ecological Reserve' (Wright and Xu, 2000).

Figure 3 shows the inter-relationships between water availability $\left(R_{\mathrm{r}}\right)$, crop water demand $\left(Q_{\mathrm{c}}\right)$ (over and above rainfall) and area dedicated to irrigation. Maximum values are established for the fractional areas of the basin that may be used for irrigation as a function of the water availability and crop water demand. For the case of $f_{\mathrm{i}}=0.4$ given in the figure, a high water-demanding crop such as sugarcane with an assumed irrigation demand of $1000 \mathrm{~mm} \cdot \mathrm{yr}^{-1}$ would reduce the $A_{\mathrm{i}} / A_{\mathrm{mu}}$ value to $<0.1$, whereas irrigation for moderate water-demanding crops such as tomato (requiring around $500 \mathrm{~mm}$ per crop) would bring this up to $0.2(20 \%)$, and for minor supplemental irrigation (requiring about $100 \mathrm{~mm} \cdot \mathrm{yr}^{-1}$ ) increasing it up to 0.8 $(80 \%)$. Perhaps the strongest message is that in almost all cases it will not be feasible to cultivate all of the land. For an area of high recharge (e.g. $R_{\mathrm{t}}=200 \mathrm{~mm} \cdot \mathrm{yr}^{-1}$ ), growing a water-intensive crop, while retaining $60 \%$ for other uses, can only be supported on $10 \%$ of the land.

\section{Role of monitoring and information}

For communities living within rural SSA, and who are regularly subjected to drought and food insecurity, the requirements for essential services such as supplies of water for human and livestock needs must obviously take predominance over other uses. Determination of what proportion of the residual component may be made available for irrigation (and commercial/ industrial) development, whilst still preserving the natural resource base, including the ecosystems dependent on groundwater, is a difficult area that must take into account the local and wider communities' needs and expectations, at present and into the future.

How can the appropriate allocation for irrigation be known a priori in the face of inadequate knowledge on the sustainable yields of aquifers? Groundwater monitoring and information systems offer the most practical and perhaps the strongest foundation for effective evaluation and management of the resource. When groundwater is developed for irrigation, the depth to the groundwater table will increase, as the system slowly acquires a new steady-state condition, based on increased removal and decreased storage and decreased

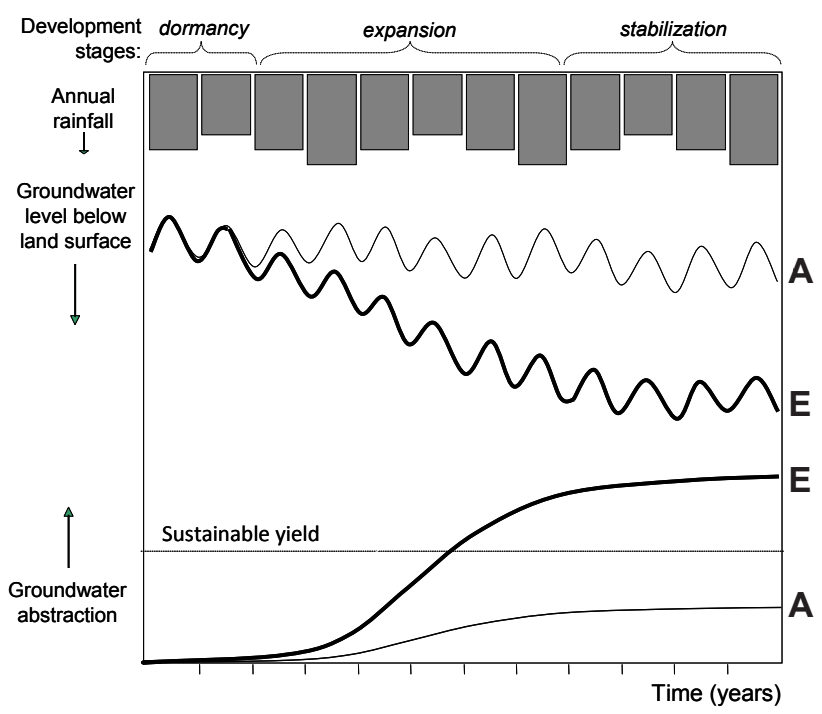

Figure 4

Idealised groundwater-level responses over the course of 3 hypothetical stages of development for 2 scenarios, Case $A$ and Case $B$

discharge to other means (e.g. to rivers and springs). Hence, a declining groundwater level may not indicate overdraft conditions, but rather the process of reaching a new stable, but deeper level (Foster et al., 2009). As continuously dropping groundwater levels over several years are a sign of excessive abstraction, it is critical to have continuous monitoring to ensure stabilisation and avoid undesirable effects. Another confounding factor when monitoring groundwater levels is the fact that groundwater levels may not drop immediately upon start of extraction, as the discharge may initially be compensated for by increased recharge from e.g. rivers and ponds. A detailed knowledge of the status of surface water/ groundwater relationships is thus a key component of any aquifer management strategy.

Consider the hypothetical examples presented in Fig. 4 that reflect 2 contrasting levels of development (A and B). Case A indicates no systematic long-term trend in groundwater levels over and above the natural seasonal variability due to intra- and inter-annual rainfall fluctuations, since the combined abstraction does not exceed the sustainable yield of the aquifer. For Case B, where development quickly rises to exceed the sustainable yield, a long-term falling trend in groundwater levels is evident. These examples support 2 main points. The first is that in the absence of firm knowledge of the future behaviour of groundwater systems, monitoring can provide an early-warning system for the avoidance of longterm and more intractable problems. Secondly, inter-annual fluctuations need to be distinguished from longer-term overdraft effects which would require monitoring and evaluation over multiple-year time-scales with concurrent monitoring at selected control points within the management unit. Such monitoring and management could be implemented by local communities that directly benefit from the development (Allaire, 2009), and in a coordinated manner with responsible government agencies. From the above, it is clear that setting limits for groundwater development cannot be determined solely from water balance and flux estimates, as groundwater levels are often the limiting factor and flows and groundwater levels are not simply correlated. 


\section{Application to case-study sites}

There are very few groundwater systems in SSA where both the recharge and discharge components of the groundwater balance have been determined with sufficient rigor. Two that are known to the authors are presented here.

\section{Atankwidi River basin, Ghana/Burkina Faso}

The Atankwidi River basin is a transboundary $275 \mathrm{~km}^{2}$ subbasin of the White Volta River basin situated in roughly equal proportions within Ghana and neighbouring Burkina Faso. The climate is subtropical with an annual rainfall of $990 \mathrm{~mm}$. The groundwater in the basin is found within the weathered crystalline basement complex, in places overlain by alluvial sedimentary deposits. The mean saturated thickness of the aquifer is around $25 \mathrm{~m}$. Hundreds of smallholder farmers have, since the 1980 s, been developing small-scale informal irrigation in the lowlands of the inland valley of the Atankwidi River. During the dry season shallow wells (dugouts) are established through manual effort within or adjacent to the dry riverbed for vegetable cultivation (predominantly tomato). Irrigation water is applied to tomatoes at an average rate of $5.5 \ell \cdot \mathrm{d}^{-1} \cdot \mathrm{m}^{-2}$, or $770 \mathrm{~mm}$ over the 20 -week cultivation period (Barry et al., 2010). Often the wells need to be deepened over the course of the irrigation season. The total area under groundwater irrigation has been estimated from ground-truthed remote sensing to be 387 ha (Barry et al., 2010). The salinity of the groundwater is low with a mean total dissolved solids (TDS) content of 130 $\mathrm{mg} \cdot \ell^{-1}$, which is non-limiting to irrigation, apart from a possible magnesium hazard (Barnie, 2010).

Through a series of studies (Martin, 2006; Barnie, 2010; Barry et al., 2010), the hydrological and hydrogeological processes within the sub-basin have been established. From those works, parameter values and ratios pertinent to this study have been summarised and are given in Table 2. Across the basin, only $3.6 \mathrm{~mm} \cdot \mathrm{yr}^{-1}$ is utilised for multiple uses, of which irrigation is estimated from a field inventory to account for $4 \%$ of total withdrawals $\left(\sim 0.1 \mathrm{~mm} \cdot \mathrm{yr}^{-1}\right)$ or just $0.2 \%$ of the annual recharge (Martin, 2006). However, when the measured value of crop water demand of $770 \mathrm{~mm} \cdot \mathrm{yr}^{-1}$ for tomato crops and the total area under groundwater irrigation is used, the $Q_{\mathrm{i}}$ accounts for $18 \%$ of $R_{t}$, a value much higher than that derived by Martin (2006). Reported groundwater-level data in the sub-basin indicate no trend, although limited to just 2 years.

Access to the groundwater system through manual lifting of water is dependent upon easy access facilitated through the shallow depths to the water table within the inland valley areas. Even though there is large uncertainty in the actual groundwater use in the basin, there are clear opportunities for expansion of irrigation, given that at least $76 \%$ of annual recharge is not abstracted and retained for the environment or uncommitted (Table 2). Ecosystems that are easily identifiable as being supported by groundwater do not occur within the sub-basin, although deep-rooted trees in lowlands may be reliant upon groundwater during the dry season in this environment (Kamagaté et al., 2007). Whilst most of the lowlands are already cultivated, there is clear scope for further groundwater development in upland areas, contingent upon suitable soil and aquifer transmissivity conditions. Lowland farmers are highly sensitive to groundwater level declines that may be caused by the combined impact of upland and lowland abstraction. Benefits and potentially adverse effects on lowland irrigators should therefore be gauged through monitoring well records and remedial actions taken locally before problems become entrenched.

\section{lullemmeden Basin, SW Niger}

The part of the Iullemmeden Basin within south-western Niger has a Sahelian semi-arid climate and annual rainfall of 560 $\mathrm{mm}$. The unconfined aquifer belongs to the tertiary Continental Terminal aquifer and is made up of unconsolidated silts and

\begin{tabular}{|c|c|c|}
\hline \multicolumn{3}{|c|}{$\begin{array}{c}\text { Table } 2 \\
\text { Hydrological and water balance characteristics for } 2 \text { case-study sites } \\
\end{array}$} \\
\hline \begin{tabular}{|ll} 
Characteristics & Site \\
\end{tabular} & Atankwidi Basin, Ghana/ Burkina Faso & lullemmeden Basin, SW Niger \\
\hline Typology & $\begin{array}{l}\text { Weathered basement aquifer, minor } \\
\text { groundwater irrigation for vegetables via } \\
\text { manual lifting in river valleys }\end{array}$ & $\begin{array}{l}\text { Sedimentary (porous) aquifer, irrigation for } \\
\text { fresh vegetables via manual lifting in wells } \\
\text { in palaeo-river valleys }\end{array}$ \\
\hline Rainfall $\left(\mathrm{mm} \cdot \mathrm{yr}^{-1}\right)$ & 990 & 560 \\
\hline Area of management unit, $A_{\mathrm{mu}}$ (ha) & 27500 & 50000 \\
\hline Total recharge, $R_{\mathrm{t}}\left(\mathrm{mm} \cdot \mathrm{yr}^{-1}\right)^{(1)}$ & 60 & 25 \\
\hline Ambient storage $(\mathrm{mm})$ & 1350 & 3600 \\
\hline Pumping rate, $Q_{\mathrm{d}}+Q_{1}+Q_{\text {in }}+Q_{\mathrm{i}}\left(\mathrm{mm} \cdot \mathrm{yr}^{-1}\right)$ & $3.6-504^{(2)}$ & 0.3 \\
\hline Groundwater irrigated area, $A_{\mathrm{i}}(\mathrm{ha})$ & 387 & unknown ${ }^{(4)}$ \\
\hline$Q_{\mathrm{i}} / R_{\mathrm{t}}(-)$ & $0.002-0.18^{(2)}$ & $<0.01^{(5)}$ \\
\hline$\left(Q_{\mathrm{d}}+Q_{\mathrm{l}}+Q_{\mathrm{in}}+\mathrm{Q}_{\mathrm{i}}\right) / R_{\mathrm{t}}(-)$ & $0.06-0.24^{(2)}$ & 0.01 \\
\hline$\left(Q_{\mathrm{e}}+Q_{\mathrm{uc}}\right) / R_{\mathrm{t}}(-)$ & $0.76-0.94$ & 0.99 \\
\hline$Q_{\mathrm{e}} / R_{\mathrm{t}}(-)$ & $\mathrm{NA}^{(3)}$ & $0.04-0.08^{(6)}$ \\
\hline Groundwater level trend & Stable (2 years) & Rising ( $>20$ yrs) \\
\hline Data sources & $\begin{array}{l}\text { Martin (2006); Barnie (2010); Barry et al. } \\
\text { (2010) }\end{array}$ & Favreau et al. (2009); Favreau et al. (2011) \\
\hline
\end{tabular}

(1) Estimated from chloride mass balance (Atankwidi) and groundwater level fluctuations (Iullemmeden)

(2) Estimates from Martin (2006) (min.) and Barry et al. (2010) (max.)

(3) $N A=$ not available

(4) Limited to valleys ( $10 \%$ of the landscape)

(5) Estimation based on water-use surveys in 2003-2004 (Favreau et al., 2009)

(6) Present-day estimate considering that total recharge was almost entirely used by the environmental component in the 1950s 
fine sands. The mean saturated thickness of the aquifer is around $30 \mathrm{~m}$. Groundwater is relied upon extensively for domestic and livestock supplies. Interestingly, the water table across this part of the basin has risen by $4 \mathrm{~m}$ on a continual basis since the 1960s. This phenomenon is attributed to widespread clearing of deep-rooted trees with the change in land use from natural savannah to millet production, reducing evapotranspiration and enhancing runoff to closed depressions that in turn leads to recharge enhancement (Leduc et al., 2001). Recharge is estimated to be $25 \mathrm{~mm} \cdot \mathrm{yr}^{-1}$, or an order of magnitude higher than the pre-clearing (1950s) values (Favreau et al., 2009). The shallow groundwater quality is highly suited to agriculture (median value of total dissolved solids of $\sim 45$ $\left.\mathrm{mg} \cdot \ell^{-1}\right)$.

Currently, limited groundwater irrigation occurs within smallholder farms, each being less than 1 ha in extent. Although the total area under irrigation and volumes used are unknown, the estimated values are lower than any other component of the groundwater balance (Table 2). Total groundwater use in the $500 \mathrm{~km}^{2}$ area to the east of Niamey is a small proportion of recharge, with the residual component in relative terms $\left(Q_{\mathrm{e}}+Q_{\mathrm{uc}} / R_{\mathrm{t}}\right)$ estimated to be 0.99 in the $1990 \mathrm{~s}$ to 2000s following the land-use change and associated recharge enhancement. The groundwater system was largely at equilibrium in the 1950 s when discharge occurred via evapotranspiration of deep-rooted trees and small fluxes to the Niger River (Favreau et al., 2009). Present-day values of the environmental component $\left(Q_{\mathrm{e}} / R_{\mathrm{t}}\right)$ are estimated to be 0.04 to 0.08 , assuming that anthropogenic groundwater use in the 1950s was less than that used at present and that the environmental requirement of the area is unchanged since the 1950 s, thereby giving a $Q_{\text {uc }}$ ' $R_{\mathrm{t}}$ value of $\sim 0.91$. At the aquifer scale, a more conservative approach would be to increase the environmental requirements for natural groundwater outflow (deep-rooted tree transpiration and discharge to the Niger River; Favreau et al., 2011). In terms of the development potential of the resource there are extensive opportunities for expanding groundwater use in the area, irrespective of the $Q_{\mathrm{uc}} / R_{\mathrm{t}}$ uncertainties. For example, utilising only half of the uncommitted fraction of 0.91 to support a crop requiring $1000 \mathrm{~mm} \cdot \mathrm{yr}^{-1}$ would enable an additional $1.1 \%$ (or $570 \mathrm{ha}$ ) of the entire management unit to be utilised for irrigation. This represents about a 50\% increase in the area under irrigation for the country, and is greater than the total areas under irrigation for 4 of the countries presented in Table 1.

\section{Conclusions}

Groundwater is highly relied upon for drinking supplies across SSA, but to date, development for smallholder irrigation has been limited. The region is characterised by a scarcity of data and general lack of knowledge on groundwater systems, including the groundwater balance that makes it difficult to find answers to questions related to development.

A simple, analytical framework based on a groundwater balance is presented that is intended to aid initial decisionmaking on groundwater allocation for irrigation and the potential areal extent under different cropping choices. The approach requires the user to account for competing groundwater uses, including basic water needs and environmental requirements, making a number of simplifying assumptions.

The first of 2 case studies from the Atankwidi sub-basin located along the Ghana-Burkina Faso border demonstrates that smallholder irrigation has the potential to emerge alongside domestic and other supplies. The second case study from
SW Niger also reveals opportunities for expansion of agricultural groundwater use that capitalises on recent hydrological changes brought about by widespread land clearing. The lesson from both studies is that the untapped development potential may be realised with sufficient understanding of the demandand-supply balance, supported by the inclusion of monitoring and evaluation systems. The analysis also demonstrates that in almost all practical cases, groundwater availability will restrain irrigation development rather than land area.

The Atankwidi case suggests that development of irrigation supplies can have unintended impacts as the socio-economic capacity of various communities (and within communities) is not always the same. The classic example is large-scale commercial farmers drawing down water levels that are most heavily felt by smallholder farmers with limited capacity to drill deeper wells and increase pump capacities. With monitoring strategies and local management in place these aspects can be foreseen and steps taken to rectify problems as they emerge. Cases of groundwater over-exploitation are also known, such as the Haramaya watershed in eastern Ethiopia (Alemayehu et al., 2007), affirming that the limited case studies presented here do not offer a complete picture for SSA.

This work also highlights that very few case studies are available with sufficient data to test the approach across a range of hydrogeological settings, and perhaps to ideally draw out generic findings for SSA. Work of this kind is needed. Furthermore, large uncertainties are associated with the estimation of components of the groundwater balance in terms of recharge and abstraction as well as the needs of the environment. Hence, it is proposed that the method be used to give a first estimation of irrigation potential and as a means to identify where effort is required to ascertain the most critical groundwater-balance values.

\section{Acknowledgements}

This work contributes to a research project led by the International Water Management Institute (IWMI) and financially supported by the Rockefeller Foundation through Project Number 2008-AGR-305, entitled 'Groundwater in Sub-Saharan Africa: Implications for Food Security and Livelihoods' and administered through the CGIAR Research Program on Climate Change, Agriculture and Food Security (CCAFS). The authors are grateful for the constructive comments received from 2 anonymous reviewers of the manuscript.

\section{References}

ADELANA SMA and MACDONALD AM (2008) Groundwater research issues in Africa. In: Adelana SMA and MacDonald AM (eds.) Applied Groundwater Studies in Africa. IAH Selected Papers on Hydrogeology, Volume 13. CRC Press/Balkema, Leiden, the Netherlands. 43-64.

ALEMAYEHU T, FURI W and LEGESSE D (2007) Impact of water overexploitation on highland lakes of eastern Ethiopia. Environ. Geol. 52 (1) 147-154.

ALLAIRE M (2009) Drought Mitigation in Semi-Arid Africa: The Potential of Small-Scale Groundwater Irrigation. SustainUs: U.S. Youth for Sustainable Development. URL: http://sustainus.org/ docs/citsci/winners/2009/Maura\%20Allaire.pdf(Accessed 5 March 2010).

ALLEY WM and LEAKE SA (2004) The journey from safe yield to sustainability. Ground Water 42 (1) 12-16.

BARNIE S (2010) Hydrogeological and Hydrochemical Framework of Groundwater for Irrigation in the Atankwidi Sub-Basin of the White Volta Basin. M.Sc. Thesis, Kwame Nkrumah University of 
Science and Technology, Department of Civil Engineering, Ghana. BARRY B, KORTATSI B, FORKUOR G, GUMMA MK, NAMARA R, REBELO L-M, VAN DEN BERG J and LAUBE W (2010) Shallow Groundwater in the Atankwidi Catchment of the White Volta Basin: Current Status and Future Sustainability. International Water Management Institute (IWMI) Research Report No. 139. DOI:10.5337/2010.234. 30 pp.

DILLON P, GALE I, CONTRERAS S, PAVELIC P, EVANS R and WARD J (2009) Managing aquifer recharge and discharge to sustain irrigation livelihoods under water scarcity and climate change. Proc. Joint IAHS \& IAH Convention. September 2009, Hyderabad, India. IAHS Publ. 330. 1-12.

DÖLL P, LEHNER B and KASPAR F (2002) Global modeling of groundwater recharge. In: Schmitz GH (ed.) Proc. Third International Conference on Water Resources and the Environment Research Vol. I, 22-25 July 2002,Technical University of Dresden, Germany. ISBN 3-934253-17-2. 27-31.

FAOSTAT (2011) An on-line multilingual database providing timeseries and cross sectional data relating to food and agriculture for some 200 countries. URL: http://faostat.fao.org/ (Accessed 4 May 2011)

FAVREAU G, CAPPELAERE B, MASSUEL S, LEBLANC M, BOUCHER M, BOULAIN N and LEDUC C (2009) Land clearing, climate variability, and water resources increase in semiarid southwest Niger: A review. Water Resour. Res. 45 W00A16. DOI: 10.1029/2007WR006785.

FAVREAU G, NAZOUMOU Y, LEBLANC M, GUERO A and GONI IB (2011) Groundwater resources increase in the Iullemmeden Basin, West Africa. Chapter 7 in: Treidel H, Martin-Bordes JL and Gurdak JJ (eds.) Climate Change Effects on Groundwater Resources: A Global Synthesis of Findings and Recommendations. IAH - International Contributions to Hydrogeology (27). CRC Press Inc., Leiden, The Netherlands. 113-128.

FOSTER S, PERRY C, HIRATA R and GARDUÑO H (2009) Groundwater resource accounting: critical for effective management in a 'changing world'. $G W \cdot M A T E$ Case Profile 16. Briefing Note Series No. 16. World Bank, Washington D.C., USA. 12 pp.

GIORDANO M (2005) Agricultural groundwater use in Sub-Saharan Africa: What do we know and where should we go? Water Polic. 7 613-626.

GIORDANO M (2006) Agricultural groundwater use and rural livelihoods in Sub-Saharan Africa: A first-cut assessment. Hydrogeol. J. 14 (3) $310-318$.

HAGOS F, MAKOMBE G, NAMARA RE and AWULACHEW SB (2009) Importance of Irrigated Agriculture to the Ethiopian Economy: Capturing the Direct Net Benefits of Irrigation. IWMI Research Report No. 128. International Water Management Institute, Colombo, Sri Lanka. 37 pp.

KAMAGATÉ B, SÉGUIS L, FAVREAU G, SEIDEL J-L, DESCLOITRES M and AFFATON P (2007) Hydrological processes and water balance of a tropical crystalline bedrock catchment in Benin (Donga, upper Ouémé River). C.R. Geoscience 339 418-429.

KAY M (2001) Smallholder Irrigation Technology: Prospects for
Sub-Saharan Africa. IPTRID, Knowledge Synthesis Report No. 3. FAO, Rome.

LEDUC C, FAVREAU G and SCHROETER P (2001) Long-term rise in a Sahelian water-table: The Continental Terminal in South-West Niger. J. Hydrol. 243 (1/2) 43-54.

MACDONALD AM, CALOW RC, MACDONALD DMJ, DARLING WG and DOCHARTAIGH BÉÓ (2009) What impact will climate change have on rural groundwater supplies in Africa? Hydrol. Sci. J. 64 690-703.

MARTIN N (2006) Development of a water balance for the Atankwidi catchment, West Africa: A case study of groundwater recharge in a semi-arid climate. Ecology and Development Series No. 41. Cuvillier Verlag Göttingen, Germany. 169 pp.

MASIYANDIMA M and GIORDANO M (2007) Sub-Saharan Africa: opportunistic exploitation. In: Giordano $\mathrm{M}$ and Villholth $\mathrm{K}$ (eds.) The Agricultural Groundwater Revolution: Opportunities and Threats to Development. Comprehensive Assessment of Water Management in Agriculture Series 3. IWMI and CAB International, Wallingford.

NAMARA RE, HOROWITZ L, NYAMADI B and BARRY B (2011) Irrigation Development in Ghana: Past Experiences, Emerging Opportunities, and Future Directions. GSSP Working Paper No. 27. Ghana Strategy Support Program, Accra, Ghana.

SCANLON BR, KEESE KE, FLINT AL, FLINT LE, GAYE CB, EDMUNDS WM and SIMMERS I (2006) Global synthesis of groundwater recharge in semiarid and arid regions. Hydrol. Process. 20 3335-3370.

SEWARD P, XU Y and BRENDONCK L (2006) Sustainable groundwater use, the capture principle, and adaptive management. Water SA 32 (4) 473-482.

SHAH T, BURKE J, VILLHOLTH K, ANGELICA M, CUSTODIO E, DAIBES F, HOOGESTEGER J, GIORDANO M, GIRMAN J, VAN DER GUN J, KENDY E, KIJNE J, LLAMAS R, MASIYANDAMA M, MARGAT J, MARIN L, PECK J, ROZELLE S, SHARMA B, VINCENT L and WANG J (2007) Groundwater: A global assessment of scale and significance. In: Molden D (ed.) Water for Food, Water for Life: A Comprehensive Assessment of Water Management in Agriculture. Earthscan, London.

SIEBERT S, BURKE J, FAURES JM, FRENKEN K, HOOGEVEEN J, DÖLL P and PORTMANN FT (2010) Groundwater use for irrigation - a global inventory. Hydrol. Earth Syst. Sci. Discuss. 7 $3977-4021$.

TARHULE A and WOO M-K (1997) Characteristics and use of shallow wells in a stream fadama - A case study in northern Nigeria. Appl. Geogr. 17 (1) 29-42.

WADA Y, VAN BEEK LPH, VAN KEMPEN CM, RECKMAN JWTM, VASAK S and BIERKENS MFP (2010) Global depletion of groundwater resources. Geophys. Res. Lett. 37 L20402. DOI: 10.1029/2010GL044571.

WRIGHT KA and XU Y (2000) A water balance approach to the sustainable management of groundwater in South Africa. Water SA 26 (2) $167-170$. 
http://dx.doi.org/10.4314/wsa.v38i3.5 Available on website http://www.wrc.org.za

ISSN 0378-4738 $($ Print $)=$ Water SA Vol. 38 No. 3 International Conference on Groundwater Special Edition 2012 ISSN 1816-7950 (On-line) = Water SA Vol. 38 No. 3 International Conference on Groundwater Special Edition 2012 